\title{
Global Transformation of Employment as a Factor of Country's Labor Market Development
}

\author{
Stanislava Pasieka ${ }^{1}$, Mariana Bil $^{2}$, Maria Dmytrenko ${ }^{3} \&$ Viktoriia Krasnomovets $^{1}$ \\ ${ }^{1}$ Department of Tourism and Hotel and Restaurant Business, Cherkasy Bohdan Khmelnytsky National University, \\ Cherkasy, Ukraine \\ ${ }^{2}$ State institution "Institute of Regional Research named after M.I. Dolishniy of the NAS of Ukraine”, Ukraine \\ ${ }^{3}$ Department of Psychology of Activity in Special Situations, Cherkasy Institute of Fire Safety named after Chornobyl \\ Heroes of National University of Civil Defence of Ukraine, Ukraine \\ ${ }^{4}$ Department of Tourism and Hotel and Restaurant Business, Cherkasy Bohdan Khmelnytsky National University, \\ Ukraine \\ Correspondence: Stanislava Pasieka, Head of the Department of Tourism and Hotel and Restaurant Business, \\ Cherkasy Bohdan Khmelnytsky National University, 81 Shevchenko Boulevard, Cherkasy 18031, Ukraine. Tel: \\ 380-67-570-3573. E-mail: apaseka@ukr.net
}

Received: June 23, 2020

doi:10.5430/rwe.v11n4p62
Accepted: July 30, 2020

Online Published: August 14, 2020

URL: https://doi.org/10.5430/rwe.v11n4p62

\begin{abstract}
The global transformation of employment is a comprehensive process that changes the principles of market relations and defines the interstate commonality of requirements for the use of labor potential. In case of inconsistency of the global transformation of employment with national peculiarities, the phenomenon of global-local polarization occurs. The labor markets of countries are increasingly affected by global transformational changes, the main factors of which are humanization, dynamic scientific and technological progress, intellectualization, development of the society and the knowledge economy, the appearance of the digital economy, demographic processes, increasing resource mobility, a focus on sustainable development goals, high competition in labor markets, economic growth. Each factor causes specific changes in the labor markets with the appearance of new spheres, forms, standards, employment conditions, features of protection, spatial organization and regulation.
\end{abstract}

Keywords: global employment transformation, labor markets, global-local polarization, humanization, digital economy, basic unconditional income

\section{Introduction}

Modern labor markets are evolving in the face of increasing influence of global factors. Technological progress, rapid growth in the mobility of human, financial and information resources, the steady openness of the economies of the countries are expanding the possibilities of using labor potential outside the domestic labor market. Employment is transforming into a global phenomenon, taking on a common set of features. It needs to be investigated to identify the impact on the labor markets of countries. The results of this kind of research will help to identify priorities for the development of national labor markets in a global competitive environment while maintaining labor potential.

The purpose of the article is to deepen the theoretical and applied foundations of the research of the transformation of global employment in the context of its impact on the labor markets of countries.

The goals of the article are: to determine the content of global transformation and its features among other processes of change; disclosure of the content and main stages of employment transformation, levels of global-local polarization in case of inconsistency of global employment transformation with national characteristics; generalization of priority factors of development of labor markets of countries in the conditions of global employment transformation.

The methodology for the research of transformation in general and employment transformation in particular is actively developing in the world economic opinion. Transformation is usually considered in two major ways: as a process that represents a radical change in existing stereotypes, interests, values, principles, rather than optimizing 
and refining them; as a process that addresses all aspects of social development and takes place at all levels simultaneously and in parallel (Zhadan, 2010). Scientists prove that transformation involves the traits of evolution, revolution and reform; transformation, like the evolution, at some stage involves the accumulation of new quantitative traits, but in the next stage they transform the system into a qualitatively new state, this is already a sign of revolution; transformation, like revolution, aims at moving to qualitatively new social relations, but transformation, unlike revolution, is not carried out by violent methods (Kovtunenko, 2012).

Employment transformation is a socio-economic process that is reflected in qualitative and quantitative changes in the employment parameters of the population, in particular changes in the structure, the ratio of different spheres and forms of employment, the emergence of new forms of employment, changes in the interests and values of the employed population (Boyarchuk, 2014).

The relevance of examining the impact of employment transformation on the labor markets is confirmed by the results of the researches of many economist scholars. The calculations confirm that for developed countries, an effective employment system contributes to unprecedented rapid economic growth by increasing the accumulation of human capital and the formation of physical capital (Sim \& Oh, 2017). The labor market functions as a regulator of economic processes, its stability remains crucial in ensuring economic development (Przybyła, Kachniarz \& Hełdak 2018). Developed countries, by attracting people with higher employment potential, provide better growth rates, and hence future changes in employment patterns and growth rates will continue to be determined by the difference between countries in the "supply of skills" (Wood, 2019). The global transformation of employment in these trends should be aimed at stimulating the development of national labor markets by balancing the redistribution of labor potential.

\section{Method}

The methodological apparatus of research is formed by the general scientific methods of scientific knowledge. Dialectical approach and methods of logical and comparative analysis were used to determine the essential characteristics of research concepts, to clarify their differences from homologous phenomena and processes, to systematize the factors of development of labor markets in the conditions of global employment transformation.

\section{Results}

Employment trends in the global dimension indicate an increase in its quality characteristics. According to the International Labor Organization, in 2018, the annual growth rate of production per worker (up to the base year 2011) was 2.2, with the highest dynamics showing higher and lower-income countries ( 3.4 and 4.2, respectively), when more developed trends are present in developed countries. For comparison, the world unemployment rate in 2018 was 5.4 (for population 15 and earlier years), with high-income countries was 5.1, with higher and below-average incomes of 6.0 and 5.3 respectively, and for low-income countries was only 3.9 (Zgurovsky, 2015). Such a difference confirms that higher-income countries develop in a highly competitive labor market. This provides them with better economic results despite lower time costs, for example, working time in high-income countries is 19 hours, when in middle-income countries is 21.7, low is 28.5 (Fedorova, 2016). As a result, countries with transitional conditions suffer from the migration losses of persons with competitive labor potential. In general trends, it remains problematic to maintain gaps between countries in terms of socio-economic development (Ramazanov et al., 2019). One of the reasons for this is the negative effects of global processes on national labor markets, which are unable to compete in the current context of transformational changes in employment.

Global influences on the development of the country's labor market can be manifested from different spheres politics, economy and employment, education, culture, information environment, demographic processes and resettlement (Podgorna et al., 2020). The emergence of such spheres of influence is caused by force factors. If we think globally, processes of changes can take on the following specific characteristics:

- global reform, as a rule, is a "blurred" process, as the prerogative of reform measures is the state level. On the other hand, leverage from international organizations is steadily increasing. The standards of product quality, entrepreneurship, decent work, education, protection of intellectual property rights and more are being extended. Such global unification creates favorable preconditions for reform on a global scale. A prime example of this is the retirement age, the limit of which is within the IMF's core in the range of international lending requirements. Therefore, global reforms are becoming more widespread and imply the unification of management approaches and standards in a particular field;

- global modernization is a process of updating, modernization, as a rule, of production processes, processes of provision of services, jobs. Global modernization is an important factor in ensuring sustainable development, 
counteracting the inefficient use of natural resources by means of fixed high-wear assets. Similarly, the importance of modernization is to create better employment conditions for the population with adequate material-technical equipment, etc.;

- global innovation involves the introduction of innovative processes and innovative approaches in the use of resources (human, material-technical, natural, informational, temporal). Unlike modernization, global innovation involves creating new markets and market segments. It is the basis of revolutionary changes in scientific and technical, technological aspects. The global dimension of innovation involves the development of a network of scientific-research, innovation structures, clusters with active inter-institutional interactions, sharing of knowledge and experience;

- global transformation is a natural, long-lasting, conditioned by indirect methods of influence, a process that involves a complex change in the principles of organization of other phenomena and processes, and is often accompanied by systemic transformations. Transformation leads to the emergence of new phenomena and processes;

- the global revolution is a fast, dynamic, often driven by direct methods of influence process, which involves a complex change in the principles of organization of other phenomena and processes, the introduction of new technologies of behavior, the use of resources in the system. Revolution can be interpreted in two ways, as a violent process that arises in the face of heightened antagonism or as a process of dramatic and rapid changes that move humanity (the system) to a new stage of development. A striking example here is the industrial, scientific and technological revolution; today it is still the expected revolution of robots;

- global progress / regress is a progressive dynamic change in the level of development of humanity, which is an indicator of the effectiveness of previous actions within reforms, modernization, innovation, transformation, revolution.

Such an overview of global changes makes it possible to approach the issue of global employment transformation, to determine the factors that actualize this process and the nature of how it influences the development of the labor market in the world.

Let's find out what the essence of employment transformation is. If we focus attention on employment, the main features of the stages of its transformation are reflected in fig. 1. The post-transformation stage is especially important.

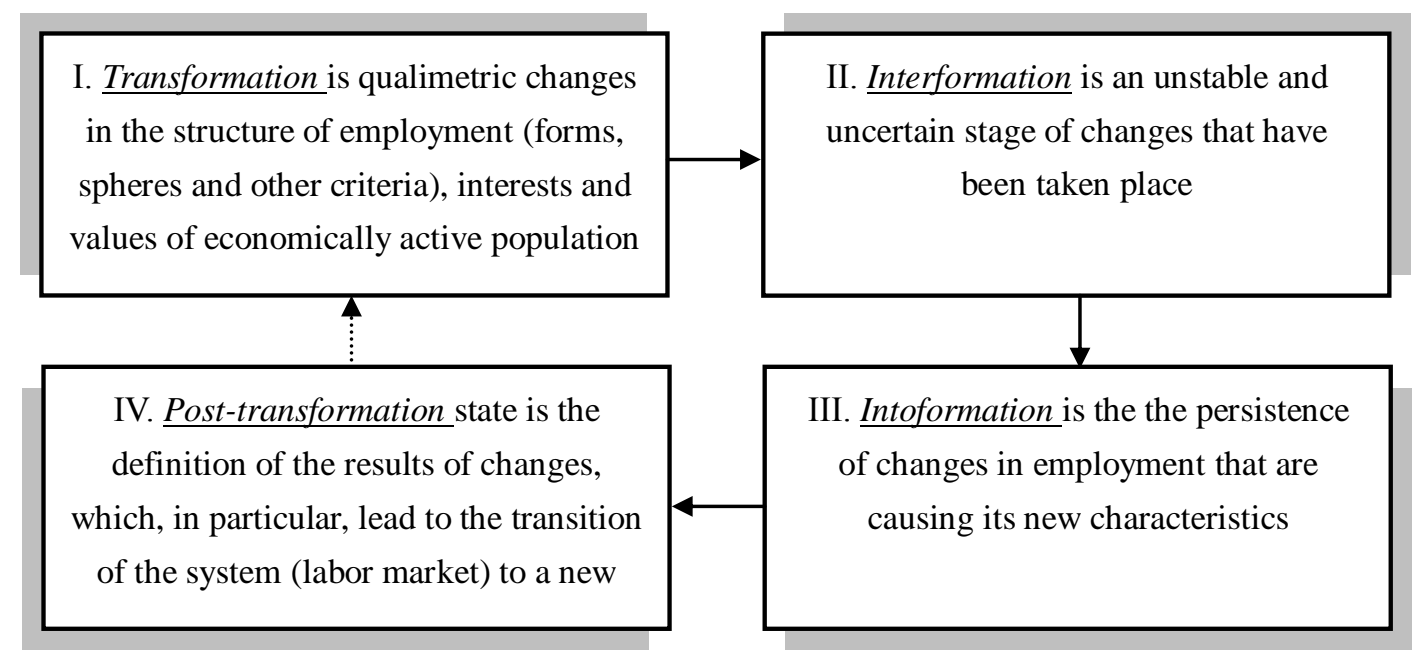

Figure 1. The main stages of employment transformation

Source: Boyarchuk, 2014

With regard to employment transformation, this stage shows the effects of systemic impact, and the closest link is employment with the labor market.

At the interstate level, the features of the global employment transformation should be explored. In our view, it is a comprehensive, supportive process represented by international organizations of changes in economic, social, cultural, and political character, reflected on the principles of forming relationships in most labor markets in the world. 
An important point is that the transformation of employment is a necessary accompanying process of transition from one stage of development of humanity and economy to another. The global transformation of employment must be in line with a new stage in human development, often determining the transition to a higher stage of development. Significantly, the transformation of global employment is not always in line with national circumstances. In this situation, there occurs a phenomenon we would like to name "global-local polarization". For example, for countries with transitional conditions, this is particularly acute in terms of matching the dominancy of a particular technological entity in the economy, which directly affects the structure of employment and its qualitative characteristics (efficiency, innovation, etc.). According to this criterion of progressive changes, such countries lag far behind developed societies. For example, for Ukraine according to the conclusions of Ukrainian experts, 95\% of the economy is based on III and IV technological structures (Zgurovsky, 2015). At the same time, the economies of developed countries are rapidly developing, being on the VI (genetic engineering, alternative energy, nanoelectronics) and VII (instrument engineering and robotics, biocomputer systems and biomedicine (communication between artificial and organic, "living" systems) technological ways (Fedorova, 2016).

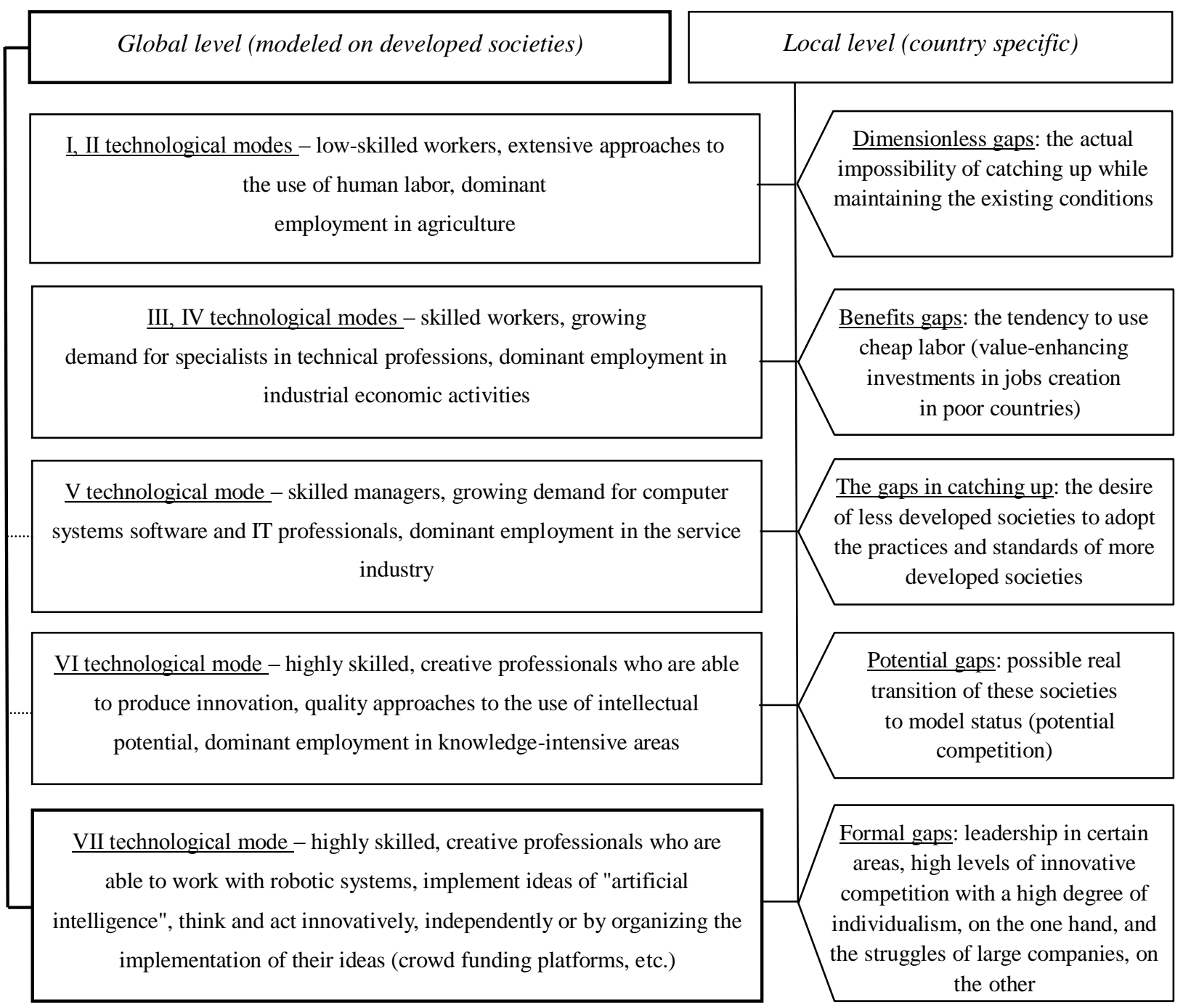

Figure 2. Levels of global-local polarization of states, depending on the dominance in the economy of the technological mode

Source: author's development

Equally strong is the inconsistency of countries with transitional conditions with global transformations in forms of employment, levels of innovation, self-employment, etc. All this generates a global-local polarization of the level of 
social development, which has a direct reflection on employment and labor market development. If such polarization persists, it results in:

- retarding of general progressive changes when leading societies are unable to stimulate development under conditions of significant backwardness of others;

- significant differentiations in terms of socio-economic development and creation of heterogeneous employment conditions;

- a deformed redistribution of human resources in the global space, with the "leakage" of intellectual potential from poorer societies and its over-concentration in more developed ones.

In Fig. 2 presents the author's vision of the magnitude of polarization depending on the country's location on a given stage of the technological establishment. Given the dominance of the priority spheres of economic development, each form has characteristic features of employment. They can be detailed. However, those shown in Fig. 2, form a general idea of the main characteristics of employment in the country. Employment in knowledge-intensive areas indicates the development of a knowledge economy. Such an economic model is a resource for intensifying the transformation of the economic space, as it is linked to the widespread dissemination of scientific knowledge, information and training, the development of workers during the life, the promotion of professional mobility, both between the public and private sectors, and between the various spheres of the professional areas; in addition, the knowledge economy contributes to the activation of transformational knowledge flows between developed and countries that are in process of developing, forming a global information and knowledge space (Shiryaev, Artemova, Zelinskaya, Novoselov, Galiullina \& Pismennaya, 2016).

Let us consider the main factors influencing the development of the labor market in the context of global employment transformations, which are especially relevant for countries with transitional conditions. Their systematic representation is given in Table. 1. Selected factors are the most significant and truly transformational. This means that they lead to changes in the principles of organization of relations within the labor market, which is accompanied by structural changes in employment and changes in the value and mental perception of the results, working conditions, opportunities for self-development and realization of the person. A specific factor in influencing global transformations of employment is also their determination of the emergence of new phenomena and processes. Therefore, in Table. 1 reveals the main effects of the factors that manifest themselves as a result of relevant structural changes in employment area.

Table 1. Priority factors for developing the labor markets of countries in the context of global employment transformation

\begin{tabular}{|c|c|c|}
\hline Factors & $\begin{array}{l}\text { The nature of the changes } \\
\text { (usually structural) }\end{array}$ & $\begin{array}{l}\text { Main implications (new phenomena and } \\
\text { processes) }\end{array}$ \\
\hline \multirow{3}{*}{$\begin{array}{l}\text { Humanization of } \\
\text { human } \\
\text { development (all } \\
\text { spheres of social } \\
\text { life) }\end{array}$} & $\begin{array}{l}\text { - Personal value-mental changes - the value of work, } \\
\text { workplace, work result, self-development } \\
\text { opportunities, working conditions (including income), } \\
\text { etc. for each person } \\
\text { - Changes in the principles of the organization of social }\end{array}$ & $\begin{array}{l}\text { - New standards of working conditions } \\
\text { - Progressive ways to protect labor rights } \\
\text { - Dissemination of volunteering, social } \\
\text { professions, secondary emplovment }\end{array}$ \\
\hline & and labor relations - the dominance of moral values & - Development of employment \\
\hline & $\begin{array}{l}\text { - Increase in employment share of persons with special } \\
\text { needs (inclusive employment) }\end{array}$ & infrastructure for persons with special \\
\hline \multirow{3}{*}{$\begin{array}{l}\text { Dynamic } \\
\text { scientific and } \\
\text { technological } \\
\text { progress }\end{array}$} & & $\begin{array}{l}\text { - Emergence of new spheres of } \\
\text { employment and new professions }\end{array}$ \\
\hline & $\begin{array}{l}\text { - Increase the share of people employed in the fields } \\
\text { that develop on the basis of VI and VII technological } \\
\text { modes }\end{array}$ & $\begin{array}{l}\text { - Increasing demands on the level of } \\
\text { technological acceptance of the employed } \\
\text { (the ability to apply innovation) }\end{array}$ \\
\hline & $\begin{array}{l}\text { - Increase of structural unemployment by reducing the } \\
\text { need for workers in the context of automation and } \\
\text { robotization }\end{array}$ & $\begin{array}{l}\text { - High dependence of work results on } \\
\text { technological support, on the one hand, } \\
\text { and significant increase in the cost of the } \\
\text { original product, manual labor, on the } \\
\text { other }\end{array}$ \\
\hline
\end{tabular}


- Increase the share of highly qualified employees

Intellectualization, development of society and economy of knowledge capable of producing innovation, on the one hand, and the lack of skilled workers of nonprofessional occupations on the other

- Social value-mental changes are the value of work results

- Increasing the value of quality work results
- New standards of educational preparation, requirements of continuous development

- Development of educational infrastructure providing formal, non-formal and informal learning

- Differentiation of methods of control and payment of work results
The emergence of the digital economy
- Increasing the share of people using distance learning and employment

- The growth of the share of self-employed and entrepreneurs in the Online Business

- Appearance of new forms of employment

- Emergence of new spheres of self-employment, entrepreneurship

- Appearance of new ways of mobilizing (collecting) the necessary resources (online platform, fundraising)

- Increasing of individual responsibility for well-being, opportunities for self-realization

- The practice of spatial breaks between employer and employee

\begin{tabular}{|c|c|c|}
\hline $\begin{array}{l}\text { Demographic } \\
\text { processes }\end{array}$ & $\begin{array}{l}\text { - Dynamic structural shifts in the context of increasing } \\
\text { pressure on market infrastructure for countries with } \\
\text { population growth } \\
\text { - Dynamic structural shifts in conditions of labor } \\
\text { shortage for countries with "leakage" of labor potential } \\
\text { (due to emigration) }\end{array}$ & $\begin{array}{l}\text { - Protectionism of the internal labor market } \\
v s \\
\text { - Openness of the labor market for persons } \\
\text { from other countries }\end{array}$ \\
\hline $\begin{array}{l}\text { Increasing } \\
\text { mobility of } \\
\text { resources, } \\
\text { including human } \\
\text { resources }\end{array}$ & $\begin{array}{l}\text { - "Duality" (double segmentation) of labor markets } \\
\text { (permanent population and migrants) }\end{array}$ & $\begin{array}{l}\text { - Wide opportunities for finding a place of } \\
\text { work, choosing the best environment for } \\
\text { development and work for everyone }\end{array}$ \\
\hline $\begin{array}{l}\text { Focus on } \\
\text { sustainable } \\
\text { development } \\
\text { goals }\end{array}$ & $\begin{array}{l}\text { - Structural changes resulting from the reorientation of } \\
\text { employment from resource-intensive sectors to service } \\
\text { industries } \\
\text { - Decrease in the share of persons working in } \\
\text { hazardous and dangerous conditions } \\
\text { - Dissemination of environmental entrepreneurship and } \\
\text { self-employment }\end{array}$ & $\begin{array}{l}\text { - High standards of employment safety } \\
\text { - Special conditions of organization of } \\
\text { labor in service economy }\end{array}$ \\
\hline $\begin{array}{l}\text { High competition } \\
\text { in the labor market }\end{array}$ & $\begin{array}{l}\text { - Favorable conditions for the development of some } \\
\text { areas characterized by an increase in the level of } \\
\text { remuneration and difficult development of those where } \\
\text { the remuneration is significantly lower } \\
\text { - Dynamic structural changes in conditions of high } \\
\text { staff turnover }\end{array}$ & $\begin{array}{l}\text { - Increase in the difference in the amount } \\
\text { of remuneration between employees of } \\
\text { different spheres and qualifications } \\
\text { - New methods of motivation, personnel } \\
\text { management }\end{array}$ \\
\hline Economic growth & $\begin{array}{l}\text { - Reducing the unemployment rate by expanding } \\
\text { employment, self-employment and entrepreneurship }\end{array}$ & $\begin{array}{l}\text { - Increasing the resources of social } \\
\text { protection for the unemployed, ways to } \\
\text { financially support the unemployed for } \\
\text { various reasons } \\
\text { - Dissemination of the practice of paying } \\
\text { basic (unconditional) }\end{array}$ \\
\hline
\end{tabular}

Source: author's development 
Let's consider some of the factors more detailed. The first is the humanization factor. In fact, this factor is fundamental because humanity, based on the principle of human priority, its life and health, determines other priorities of progressive change. Humanization of human development mainly causes the value-mental changes of personalization. They can relate to the value of different aspects of work for each individual.

The impact of the humanization factor of human development is multifaceted. Consideration should be given to strengthening each person's right to realization and development through employment, regardless of health status. Therefore, more and more popular are the practice of creating employment opportunities for persons with special needs - inclusive employment, which is accompanied by the development of inclusive education. This practice is an important condition for social responsibility of business and the state, and confirms the level of tolerance of any society.

One of the main factors influencing the development of labor markets of countries is technological, which is manifested through scientific and technological progress (see Table 1). A significant consequence of the impact of scientific and technological progress is the emergence of new areas of employment and professions. Increasing demand for new professions leads to structural changes in the occupational criteria. This, in turn, can widen the pay gap of new professions over traditional ones. Therefore, one of the important tasks of every participant in the labor market is the ability to identify these promising professions, to acquire the appropriate skills in time and to position themselves in the market. The goal of public policy is to regulate the professional structure of the employed, taking into account the interests of spatial development. For example, one of the sections of the problem for developing countries is low-productivity employment in agriculture, which is why it is important to counteract the obstacles to labor mobility for the reasonable redistribution of workers and professionals between industries (Herrendorf \& Schoellman, 2018).

The result of scientific and technological progress is the emergence of the digital economy (see Table 1), which significantly affects the labor markets of countries with the formation for the professions of the so-called probability of automation - the potential for replacement by robotic systems (Dengler \& Matthes, 2018). Particular attention should be paid to the transformational process of increasing the share of self-employed and entrepreneurs in the Online Business. Digital economy itself is a theoretical construction of the post-industrial stage of economic system development (alongside with information, innovation, knowledge, network economy) (Kolyadenko, 2016; Hrabovskyi et al., 2020). This is the economy that develops due to e-products and services produced by e-business and widespread e-commerce (Babenko et al., 2019).

The conditions of the digital economy are driving transformational change in employment. They manifest themselves in new opportunities:

1) employment and development (training) through distance learning;

2) implementation of entrepreneurial, for-profit ideas, employment in the digital economy;

3) mobilization and gathering of necessary resources through popular online platforms;

4) organization of work and business through the use of freelancing, outstaffing and other non-standard solutions.

The digital economy shapes a new plane of employment potential. If dual-market theory justifies the formation of targeted employment segments for the permanent population (citizens of a particular state) and persons in the legal status of a migrant, then the digital economy forms a third dimension of employment that is the virtual one. This significantly changes the initial principles of organization of social and labor relations and leads to the creation of spatial gaps between the employer and the employee. This situation significantly affects the labor markets (Table 2).

The impact of the digital economy on the transformation of employment and labor markets is reflected in employment opportunities in their respective fields. In addition to the "clean" spheres of the digital economy, its technical capabilities make it possible to broaden the horizons of action for implementing business ideas in traditional sectors. E-commerce provides exceptional customer search capabilities. Its benefits have a significant stimulating effect on self-employment and entrepreneurship, especially among young people. 
Table 2. Differences in employment and the development of labor markets in a traditional and digital economy

\begin{tabular}{|c|c|}
\hline TRADITIONAL ECONOMY & DIGITAL ECONOMY \\
\hline \multicolumn{2}{|c|}{ General features of employment } \\
\hline Employment in traditional sectors of the economy & Employment in the digital (virtual) economy sectors \\
\hline \multicolumn{2}{|c|}{ Initial principles of the organization of social and labor relations } \\
\hline Domination of relations with real communications & $\begin{array}{l}\text { Domination of relations with virtual communications } \\
\text { (real are very rare) }\end{array}$ \\
\hline \multicolumn{2}{|c|}{ The main transformations of employment } \\
\hline $\begin{array}{l}\text { Increase the share of knowledge-intensive people with } \\
\text { high qualification requirements }\end{array}$ & $\begin{array}{l}\text { Growth of the share of self-employed entrepreneurs } \\
\text { engaged in additional promotion, sales, search for } \\
\text { business partners, etc. }\end{array}$ \\
\hline \multicolumn{2}{|c|}{ Labor market marketing goals } \\
\hline \multirow{2}{*}{$\begin{array}{l}\text { Diverse: each of the market participants, especially } \\
\text { enterprises and organizations, as well as the state, } \\
\text { positions its own competitive opportunities } \\
\text { Multilevel: it matters marketing at different levels, that } \\
\text { is individual, enterprise and organization, settlement, } \\
\text { region, state, continent (integration formation), the } \\
\text { world }\end{array}$} & $\begin{array}{l}\text { Individualized: each market participant, especially the } \\
\text { employer and employee, positions their own competitive } \\
\text { opportunities }\end{array}$ \\
\hline & $\begin{array}{l}\text { Multilevel: state-owned marketing has a special purpose - } \\
\text { controlling the scale of virtual employment, which } \\
\text { "erodes" social protection and taxation opportunities, as } \\
\text { well as motivating the population to take up employment } \\
\text { in traditional sectors, in particular by increasing the level } \\
\text { of innovation in the economy }\end{array}$ \\
\hline
\end{tabular}

Source: author's development

It is obvious that the digital economy is shaping a new determination of entrepreneurship and employment. This places new demands on the formulation of the state employment policy and the harmonization of social and labor relations with the crossing of state borders.

Referring to other factors influencing the development of the national labor market, presented in Table. 1, we should focus mind on the determinants of economic growth. Despite the persistence of considerable economic inequality between countries, many of them have large financial resources available for redistribution. The rapid spread of automation and robotics practices has led to the release of large numbers of employees. This necessitates:

a) creating more jobs in areas where human labor is indispensable (most services, including arts, sports, etc.);

b) payment to the forced unemployed of a certain income which, under conditions of difficulties in finding a place of work, allows to satisfy material needs.

Many developed countries are in controversy over the payment of basic unconditional income. In this regard, scientists and experts have also begun to explore this concept. In particular, unconditional guaranteed income is defined as a social concept whereby every member of society is regularly provided with a fixed, state-funded (or other institute) payment for all, without exception, despite of income, social status, availability or absence of work, and desire to work (Goncharova \& Goncharova, 2016). Although for societies with transitional conditions, the payment of basic income seems to be an utopian prospect, however larger European countries are already following this path. This will encourage a significant part of our citizens not only to emigrate, but also to obtain sufficient legal status in another country (including citizenship) to access basic income payments.

The decision to pay unconditional basic income (now payments are being tested by Italy and Finland, in France it has been started raising funds for such an experiment) will significantly change the employment structure of the whole world. This will open the way to the development of those areas where technological processes, in particular artificial intelligence, play a leading role. This will be due to the fact that the release of human labor will significantly increase the demand for robotic technologies, stimulating and financially providing appropriate developments. On the other hand, many people will receive self-actualization through the payment of basic income, which will lead to an entrepreneurial and creative boom. That's why the current situation is quite interesting and groundbreaking. Countries with transitional conditions are still sidelined by these processes.

If we summarize the influence of various factors (see Table 1) on the development of the labor markets of countries, 
a dual perception is formed. We can distinguish factors that have a very strong influence on transformation processes. We are talking about the impact of scientific and technological progress, new standards of employment in the humanization of human development, rapid growth of mobility of resources and more. At the same time, in developed countries, the effects of factors that are gradually transforming the employment sphere are intensifying, and in countries with transitional conditions they are still very weak. These are the drivers of economic growth, the emergence of the digital economy, the determination of sustainable development goals. Of course, there are some reactions of the labor markets of less developed countries. A great example here is the growth of employment in information technology. However, such effects are more a response of a distorted labor market, rather than a goal-based, regulated and controlled process by the state. The spontaneity of transformations has a negative impact on the ability of labor market participants to use their labor potential and look for better conditions outside the national economic space. In this regard, employment transformation must be a subject of a regulated process, and its global determination should be regulated at the level of intergovernmental organizations.

\section{Discussion}

Thus, global transformation is a natural, long-lasting, conditioned indirect method of influence process that involves a complex change in the principles of organization of other phenomena and processes, and often accompanied by systemic transformations. This distinguishes transformation among other processes of change, such as reform, modernization, innovation, revolution, progress or regress. Global employment transformation is a comprehensive, supportive process in the face of international organizations of changes in economic, social, cultural, and political nature that are reflected in the principles of market relations. In case of inconsistency of global transformation of employment with national peculiarities, so-called global-local polarization arises. Understanding the content of the global employment transformation has made it possible to summarize the main factors for the development of labor markets in countries with a focus on the effects of humanization on humanity, the emergence of the digital economy and the prospect of paying basic unconditional income. Such results outline the priorities for regulating the development of labor markets in countries in the context of global competition and counteracting the loss of labor potential.

\section{References}

Babenko, V., Kulczyk, Z., Perevozova, I., Syniavska, O., \& Davydova, O. (2019). Factors of Development of International e-Commerce in the Context of Globalization. CEUR Workshop Proceedings, 2422, 345-356. Retrieved from http://ceur-ws.org/Vol-2422/paper28.pdf

Boyarchuk, L. V. (2014). Transformation of employment of the population as a component of socio-economic policy of the state. Bulletin of the Kharkiv National Technical University of Agriculture named after Petra Vasylenko, 150, 101-106.

Dengler, K., \& Matthes, B. (2018). The impacts of digital transformation on the labour market: Substitution potentials of occupations in Germany. Technological Forecasting and Social Change, 137, 304-316.

Fedorova, Y. V. Prospects for innovative development of Ukraine: technological modes. Bulletin of Khmelnitsky National University. Economic Sciences, 1, 123-126.

Goncharova, S. Y., \& Goncharova, A. B. (2016). The social concept of the guaranteed (basic) income of the population. Business Inform, 4, 138-142.

Herrendorf, B., \& Schoellman, T. (2018). Human Capital and Barriers to Structural Transformation. American Economic Journal: Macroeconomics, 10(2), 1-23.

Hrabovskyi, Y., Babenko, V., Al'boschiy, O., \& Gerasimenko, V. (2020). Development of a Technology for Automation of Work with Sources of Information on the Internet. WSEAS Transactions on Business and Economics, 17(25), 231-240. https://doi.org/10.37394/23207.2020.17.25

Kolyadenko, S. V. (2016). Digital economy: preconditions and stages of formation in Ukraine and in the world. Economy. Finances. Management: Topical issues in Science and Practice, 6, 105-112.

Kovtunenko, E. S. (2012). Democracy as a result of social transformation: methodological and conceptual problems of measurement. Actual problems of Sociology, Psychology, Pedagogy, 14, 26-31.

Podgorna, I., Babenko, V., Honcharenko, N., Sáez-Fernández, F. J., Fernández, J. A. S., \& Yakubovskiy, S. (2020). Modelling and Analysis of Socio-Economic Development of the European Union Countries through DP2 Method. WSEAS Transactions on Business and Economics, 17(44), 454-466. https://doi.org/10.37394/23207.2020.17.44 
Przybyła, K., Kachniarz, M., \& Hełdak, M. (2018). The impact of administrative reform on labour market transformations in large Polish cities. Sustainability (Switzerland), 10(8), 1-15.

Ramazanov, S., Antoshkina, L., Babenko, V., \& Akhmedov, R. (2019). Integrated model of stochastic dynamics for control of a socio-ecological-oriented innovation economy. Periodicals of Engineering and Natural Sciences, 7(2), 763-773. https://doi.org/10.21533/pen.v7i2.557

Shiryaev, D. V., Artemova, E. I., Zelinskaya, M. V., Novoselov, N. S., Galiullina, S. D., \& Pismennaya, E. E. (2016). "Knowledge Economy" as a Resource for the Intensification of Socio-Economic Transformation of the Regional Economic Space. International Review of Management and Marketing, 6(S1), 232-237.

Sim, S. G., \& Oh, O. (2017). Economic growth and labor market friction: a quantitative study on Japanese structural transformation. The B.E. Journal of Macroeconomics, 17(1), 1-38.

Wood, A. (2019). Globalization and Structural Change around the World, 1985-2015. The World Bank Research Observer, 34(1), 65-94.

Zgurovsky, M. Z. (Eds.) (2015). Foresight of the Ukrainian Economy. Medium term (2015-2020) and long term (2020-2030) time horizons. International Council of Scientific Unions (ICSU), National Technical University of Ukraine "Kyiv Polytechnic Institute", Institute of Applied Systems Analysis of NAS of Ukraine and DES of Ukraine, World Center for Geoinformatics and Sustainable Development. Kyiv.

Zhadan, O. V. (2010). Transformation of social-labor relations in modern society. Actual problems of public administration, 1, 298-305.

\section{Copyrights}

Copyright for this article is retained by the author(s), with first publication rights granted to the journal.

This is an open-access article distributed under the terms and conditions of the Creative Commons Attribution license (http://creativecommons.org/licenses/by/4.0/). 